\title{
Burn wound healing effects of the root hydroethanolic extract of Cochlospermum planchonii in mice
}

\author{
Kossi METOWOGO ${ }^{1}$, Nakpane FANKIBE ${ }^{1}$, Yendubé T. KANTATI ${ }^{1 *}$, Kodjo ADI ${ }^{1}$, \\ Tchin DARRÉ ${ }^{2}$, Kwashie EKLU-GADEGBEKU ${ }^{1}$ and Kodjo A. AKLIKOKOU ${ }^{1}$ \\ ${ }^{1}$ Laboratory of Physiology/Pharmacology, University of Lomé, 01BP: 1515, Lomé, Togo. \\ ${ }^{2}$ Department of Anatomy and Cytopathology, Sylvanus Olympio University Hospital Center, Lomé, Togo. \\ ${ }^{*}$ Corresponding author; E-mail: rodriguekant@gmail.com; Tel. +22890180430
}

\author{
Received: 10-09-2020
}

Accepted: 27-12-2020

Published: $31-12-2020$

\begin{abstract}
Cochlospermum planchonii is a plant traditionally used in Togo to treat burn wounds. The present study aimed at evaluating the effect of the root hydroethanolic extract of Cochlospermum planchonii on the skin burn wounds. Burns were induced in ICR mice by applying on the skin of the dorsal region a metal stick $(0.7 \mathrm{~cm}$ diameter) preheated at $100{ }^{\circ} \mathrm{C}$ for 10 seconds. Four (4) groups of 8 mice were formed, Control Group (I); Group II, III and IV treated respectively with $C$. planchonii gel $2.5 \%, 5 \%$, and Brulex® (Zinc oxide $15 \%$ cream). The surfaces of the wounds were evaluated daily by the ImageJ software. Biopsies were performed on day six and twelve for hydroxyproline assays and histological examinations. On the 12th day, wound contraction rates were $44.12 \%, 67.82 \%, 66.68 \%$ and $69.32 \%$ respectively for Group I, Group II, Group III and Group IV. Hydroxyproline levels on day 12 were significantly higher in samples of animals treated with C. planchonii $2.5 \%$ and $5 \%(+114,93 \pm 1,61$ and $+120,54 \pm 7,22$ of augmentation respectively, $\mathrm{P}<0.01$ when compared to the control Group). Histological examination confirmed these observations. C. planchonii root hydroethanolic extract could be a potentially natural remedy for burn wound.
\end{abstract}

(C) 2019 International Formulae Group. All rights reserved.

Keywords: Cochlospermum planchonii; Carbopol gel, burn wound; hydroxyproline fibroblasts, ICR mice.

\section{INTRODUCTION}

Worldwide, burns are responsible for more than 300.000 deaths annually, including 95.000 children less than 20 years of age with disparities 11 times higher in low-income countries (Peden et al., 2008). These data are most likely underestimated because underdeveloped countries do not have accurate statistics.

Since prehistory, plants and their byproducts were used to treat wounds (Adjakpa et al., 2016; Barros et al., 2017). For a while, several studies have been interested in studying the proprieties of plants to heal burn wounds. Among these researches, those carried out on Buchholzia coriacea (Izah et al., 2018), Elaeis guineensis (Sene et al., 2020), and Sauromatum guttatum (Said et al., 2019) can be cited. Cochlospermum planchonii is a plant that has been the subject of several scientific studies. Its roots are used in West African pharmacopoeia to treat several diseases, including hepatic fever, malaria fever, jaundice, and haemolytic anaemia (Yakubu et al., 2010). The roots are traditionally used in Togo to treat burn wounds, but no scientific study has proven its 
effectiveness. Previous studies in our laboratory have shown the presence of secondary metabolites such as flavonoids, tannins, carbohydrates, sterols, triterpenes, and saponosides in the leaves and root hydroethanolic extracts of this plant (Fankibe et al., 2020). Elsewhere, numerous pharmacological properties have been reported, including: anti-malarial activity in vitro against Plasmodium falciparum (Benoit-Vical et al., 2001); anti-inflammatory and antihyperglycemic properties (Yoda et al., 2020); hepatoprotective activity (Anaga and Oparah, 2009), inhibitory activity on Toxoplasma Gondii (Benoit-Vical et al., 2000), anti-microbial proprieties (Isah et al., 2013; Fankibe et al., 2020). Our objective in approaching this work was to evaluate the healing effect of this plant on skin burns model in mice.

\section{MATERIALS AND METHODS Plant material}

The roots of Cochlospermum planchonii were harvested in Kabou, Bassar (TOGO) in the month of July 2016. A voucher specimen was identified and deposited in the herbarium of Laboratory of Botany and Plant Ecology under the number TOGO 15501. The samples collected were dried under air conditioning in the Laboratory of Physiology and Pharmacology of the Faculty of Sciences of the University of Lomé.

\section{Preparation of the hydroethanolic extracts}

The dried roots of $C$. planchonii were ground to powder and $300 \mathrm{~g}$ of each was macerated in 4 litres of ethanol-water mix (5:5. $\mathrm{v} / \mathrm{v})$ for 72 hours. The filtrate was then evaporated under vacuum at $40{ }^{\circ} \mathrm{C}$ using a rotavapor (Buchi R- 210) (Fankibe et al., 2020). The extraction yields were calculated following equation:

Yield $(\%)=(\mathrm{W} 1 \times 100) / \mathrm{W} 2$

where, W1 is the weight of the extract residue obtained after evaporation and W2 is the weight of dried roots or leaves powder used.

\section{Reagents}

P-dimethylaminobenzaldehyde was provided by VWR International (Haasrod, Belgium). All other chemicals and reagents used were of the analytical grade.

\section{Gel preparation}

The gel was prepared following previously described methods (Natas et al., 2008). $0.50 \mathrm{~g}$ of Carbopol (Goodrich, USA) was dispersed in $49.5 \mathrm{~g}$ of distilled water. The assembly was continuously stirred using a magnetic stirrer (IKA Magnetic Stirrer IKA Combimag RCT) at $800 \mathrm{rpm}$ for one hour. The mixture, which was always stirred, was neutralized by drip addition of a $1 \mathrm{M} \mathrm{NaOH}$ solution. We obtained a translucent gel. Three types of gel formulations were prepared: the gel consisting only of Carbopol (1\%), the gels containing $2.5 \%$, and $5 \%$ hydroethanolic extract of $C$. planchonii.

\section{Animals}

Thirty-two females ICR mice (25-35 g) were used for these experiments. Animals were raised in the animal house of the Faculty of Science of the University of Lomé, housed in standard polypropylene cages and maintained under standard laboratory conditions (temperature $24-25^{\circ} \mathrm{C}$, relative humidity and a $12 \mathrm{t} / 12 \mathrm{~h}$ light-dark cycle). They had free access to food and water. Principles of laboratory animal care as described in institutional guidelines and ethics of Laboratory of Physiology/Pharmacology of University of Lomé-Togo (ref: 001/2012/CB-FDS-UL) were followed.

\section{Burns wounds induction}

The mice were anaesthetized with formaldehyde and then the back hair was removed with an electric razor. The burns were induced by applying for 10 seconds a metal stick $\left(0.7 \mathrm{~cm}\right.$ diameter) preheated at $100{ }^{\circ} \mathrm{C}$. The burns obtained by this technique are of deep second degree (Koizumi et al., 2009; Haghdoost et al., 2016). The mice were randomly divided into four (4) groups of 8 mice according to the treatments to be carried out. 
- Group I: represents the mice that were treated with empty gel Carbopol (control treatment);

- Group II: represents the mice that were treated with $2.5 \%$ C. planchonii mixed in Carbopol gel;

- Group III: represents the mice that were treated with $5 \%$ C. planchonii mixed in Carbopol gel;

- Group IV: represents the mice that were treated with reference cream Brulex ${ }^{\circledR}$ (zinc oxide $15 \%$ ).

After topical application of creams, the wound was covered with the sterile plain gauze for 24 hours. Each group of mice was treated once a day for 12 days, starting from the wound induction until day 12 post-induction.

\section{Measurement of wound area}

The images of the wounds were taken every day using the same instrument (Sony DSC-HX60V Digital Camera) and settings, fixed distance of the camera from the wound and the same position of rats. Then the photos were analysed, and the wound area of each animal was evaluated every day till day 12 , using the Image J $1.48 \mathrm{v}$ freeware [(National Institutes of Health, USA; https://imagej.nih.gov/ij), 2774K, 640MB, < 1\%] (Nicoli et al., 2008; Agra et al., 2013). The healing rates $(\mathrm{Tx})$ were calculated from the wound surface values using an equation:

\section{$\operatorname{Tx}(\%)=[(\mathrm{A} 0-\mathrm{At}) / \mathrm{A} 0] \times 100$}

where $\mathrm{A} 0$ is the original wound area, and at is the area of wounds on days' $\mathrm{x}$ postwound induction.

\section{Histological studies}

On the sixth day, 3 mice from each group were anaesthetized with formaldehyde and sacrificed. Wounds were collected for histological analysis. On day 12, the remaining mice in all groups were sacrificed by cervical dislocation for histological testing and hydroxyproline assay. The biopsies planned for the histological tests were stored in $10 \%$ formalin. Skin wound samples were fixed in $10 \%$ neutral buffered formalin, processed and included in paraffin. Five-micrometer skin sections were cut and stained with haematoxylin-eosin $(\mathrm{H} \& \mathrm{E})$. The tissues were qualitatively assessed under light microscopy (Olympus BX 51) at 200 x magnification. Parameters such as granulation, epithelialisation, vascularisation and inflammatory cells were highlighted.

\section{Determination of hydroxyproline}

Hydroxyproline is an amino acid index of collagen synthesis. It was measured on day 12 using previously described methods (Darré et al., 2014). Briefly, fragments were dried in an incubator at $60^{\circ} \mathrm{C}$ for 12 hours. The samples were then digested in $\mathrm{HCl} 6 \mathrm{~N}$ for 4 hours at $130{ }^{\circ} \mathrm{C}$ in glass tubes hermetically closed. The hydrolysates were completed with $10 \mathrm{ml}$ of distilled water, and to this volume was successively added $0.5 \mathrm{~mL} \mathrm{CuSO}$ (0.01M), $0.5 \mathrm{~mL}$ of $\mathrm{NaOH}(2.5 \mathrm{~N})$ and $0.5 \mathrm{ml}$ of $\mathrm{H}_{2} \mathrm{O}_{2}$ $(6 \%)$. The solutions obtained were mixed by vortexing and incubated in an oven at $80^{\circ} \mathrm{C}$ for sixteen minutes. After cooling to room temperature, $2 \mathrm{ml}$ of $\mathrm{H}_{2} \mathrm{SO}_{4}(3 \mathrm{~N})$ was added, and the solutions were vortexed. One (1) mL of a 5\% P-dimethylaminobenzaldehyde solution was added and the absorbances were read with a spectrophotometer at $540 \mathrm{~nm}$. Standard solutions of $1.0,2.0,4.0,8.0$, and $16.0 \mathrm{mg} / \mathrm{mL}$ of hydroxyproline were also prepared in triplicate to make a calibration curve.

\section{Statistical analysis}

Results are presented as percentages and means with standard error of the mean (M \pm SEM). One-way Analysis of variance test (ANOVA) followed by the Bonferoni was used. GraphPad Prism 6.05 software (San Diego, USA) was used. Values of $\mathrm{P}<0.05$ were considered significant.

\section{RESULTS}

\section{Extraction yields}

The yields of $27.21 \%$ was obtained for root extract.

\section{Wound healing effect}

On first hand, the daily wound surfaces were monitored and presented in Figure 1A. Analysis of the variance shows a nonsignificant difference between wound surfaces in all groups up to the 4 th day of treatment. 
From day 6 to day 12 significant differences were found between control mice and those treated with $2.5 \%, 5 \%$ extract and Brulex ${ }^{\circledR}$ $(\mathrm{P}<0.01)$. The differences in healing observed between the treatments with $2.5 \%, 5 \%$ extracts and Brulex ${ }^{\circledR}$ are not significant.

On second hand, wound surfaces were used to calculate the areas of contraction shown in Figure 1B. There is an almost zero contraction rate on the 1st and 2nd day for all treatments. From the 3rd day, a difference between treated group and control was noted, difference which exacerbated on day four. On the 6th day of observation, the mice treated with $2.5 \%, 5 \%$ extracts and those of the Brulex ${ }^{\circledR}$ reference showed a better contraction compared to the control group, with rates of $44.12 \%, 67.82 \%, 66.68 \%$, and $69.32 \%$ respectively for the control Group, extract $2.5 \%$, extract $5 \%$ and the Brulex ${ }^{\circledR}$ reference (Figure 1B) on the 12th day.

\section{Collagen content}

According to the Figure 2, Cochlospermum planchonii alcoholic extract in gel favoured the production of collagen as demonstrated by the hydroxyproline content. Significant difference was observed between the hydroxyproline content of the control group and Group II, Group III and Group IV. The differences observed between mice in Group II, Group III and Group IV were not significant.

\section{Histological study}

Histological sections performed on the sixth day show a fairly elaborate granulation tissue in mice treated with the hydroethanolic extract $2.5 \%, 5 \%$ and the reference cream, while a significant influx of inflammatory cells is still observed in control mice (Figure 3, Table 1). On the twelfth day, there is a significant neovascularization and fleshy bud in the cuts of mice treated with $2.5 \%, 5 \%$ gel and control gel. In control mice, there is only a small neovascularization (Figure 3, Table 2).

On day 6 , in the control group (A), collagen bundles, a significant influx of inflammatory cells and thrombosis of capillary vessels were observed (Table 1). For groups II, III and IV, i.e. B, C and D, denaturation of the collagen bundles, moderate presence of inflammatory cells, and detachment epithelialization were observed.

On day 12, in the control group (A), some inflammatory cells were still observed, with little neovascularisation in a bundle of collagen fibers. In $\mathrm{B}, \mathrm{C}$ and $\mathrm{D}$ there is an absence of inflammatory cells, neoangiogenesis from the capillary vessels around the burned area, neo- formed collagen fibers and a fairly large fleshy bud, as shown in Table 2.
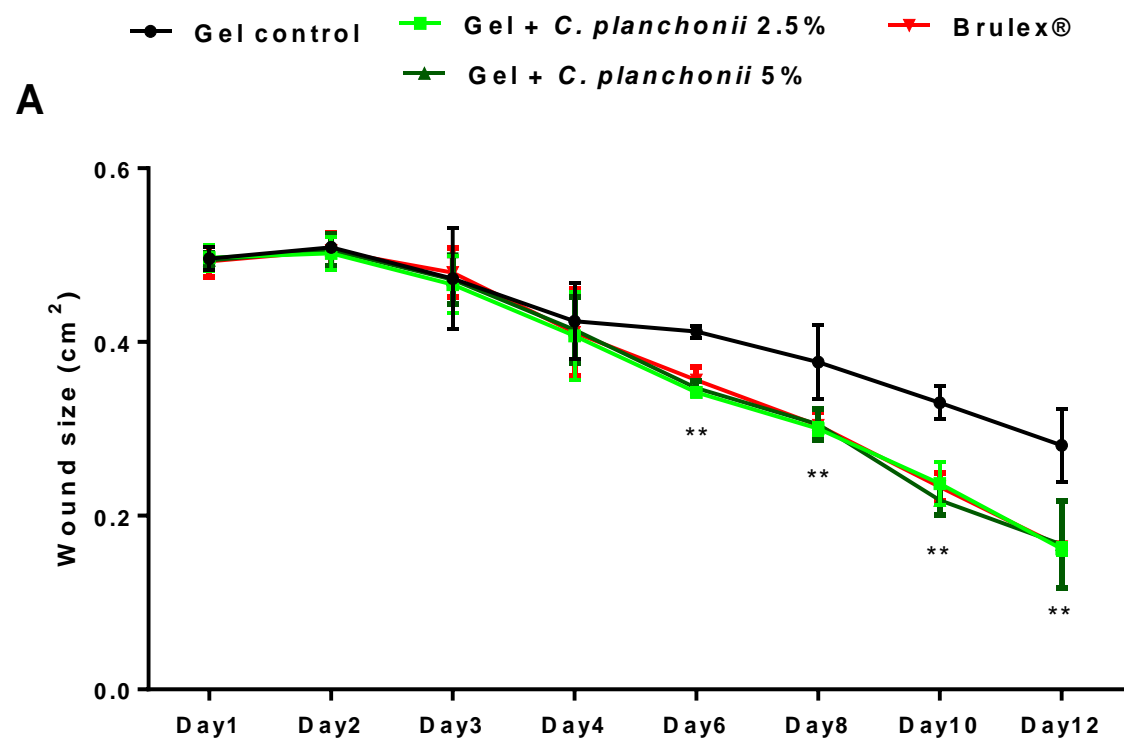


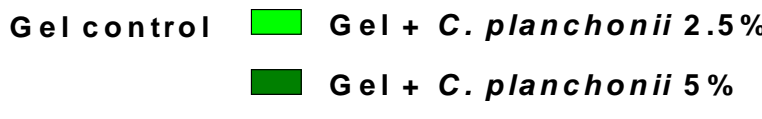

B

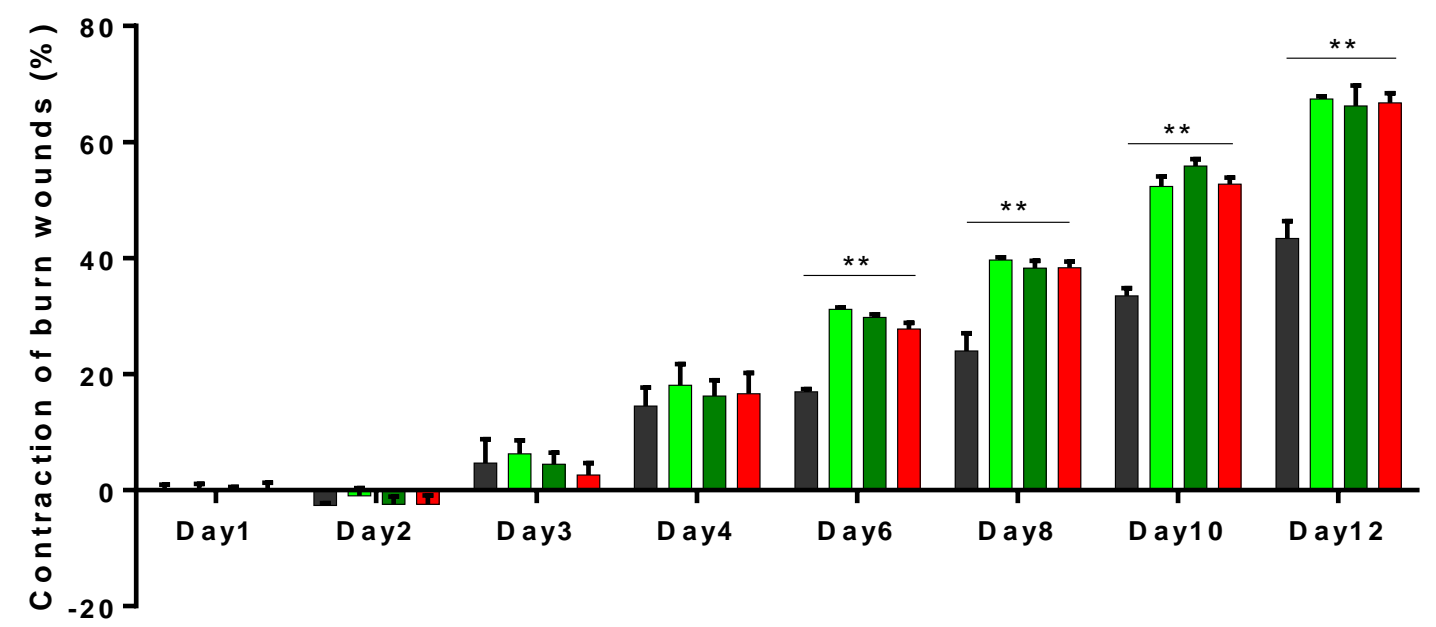

Figure 1: Effect of topical application of Cochlospermum planchonii in gel on the size of burn wounds (A) and the rates of contractions correspondent (B).

The values are expressed as Mean \pm SEM, $\mathrm{n}=8$. Units: $\mathrm{cm}^{2}(\mathrm{~A})$ and $\%$ (B). $* * \mathrm{p}<0.01$ significant when compared to the Gel control group.

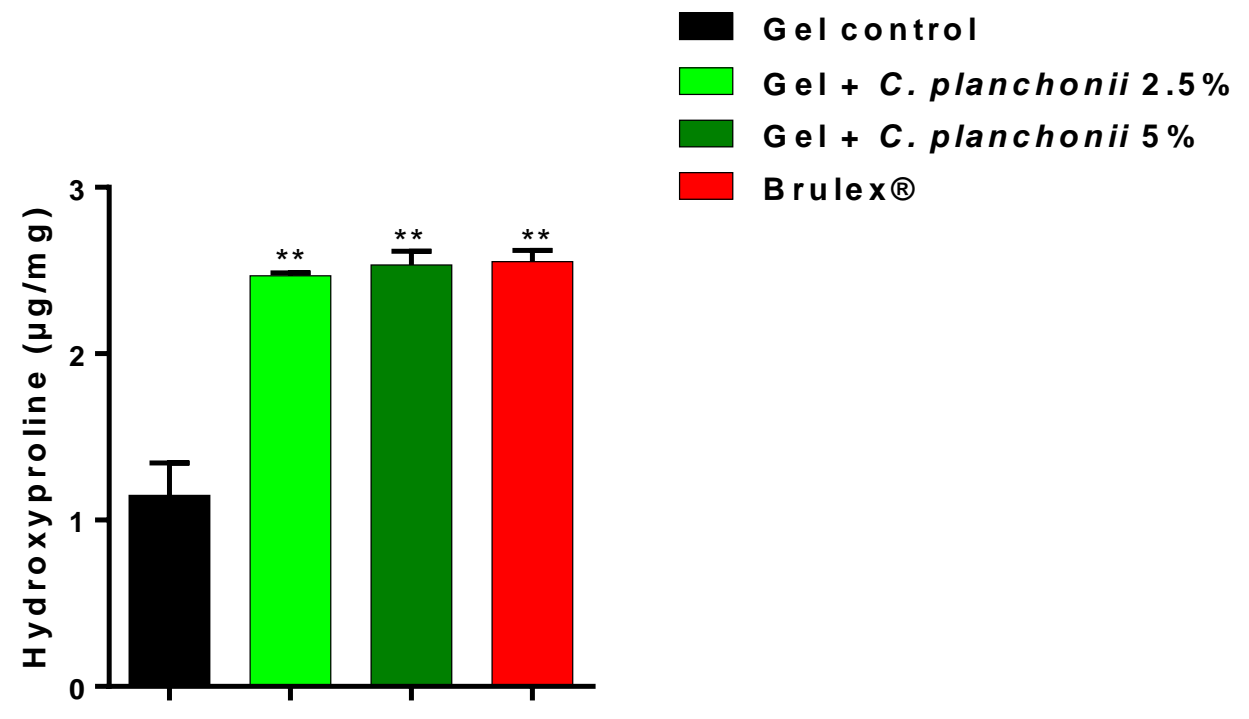

Figure 2: Effect of topical application of C. planchonii mixed in Carbopol gel on hydroxyproline levels on day 12 .

The values are expressed as Mean $\pm \mathrm{SEM}, \mathrm{n}=8$. Units: $\mu \mathrm{g} / \mathrm{mg}$. **p $<0.01$ significant when compared to the Gel control group. 

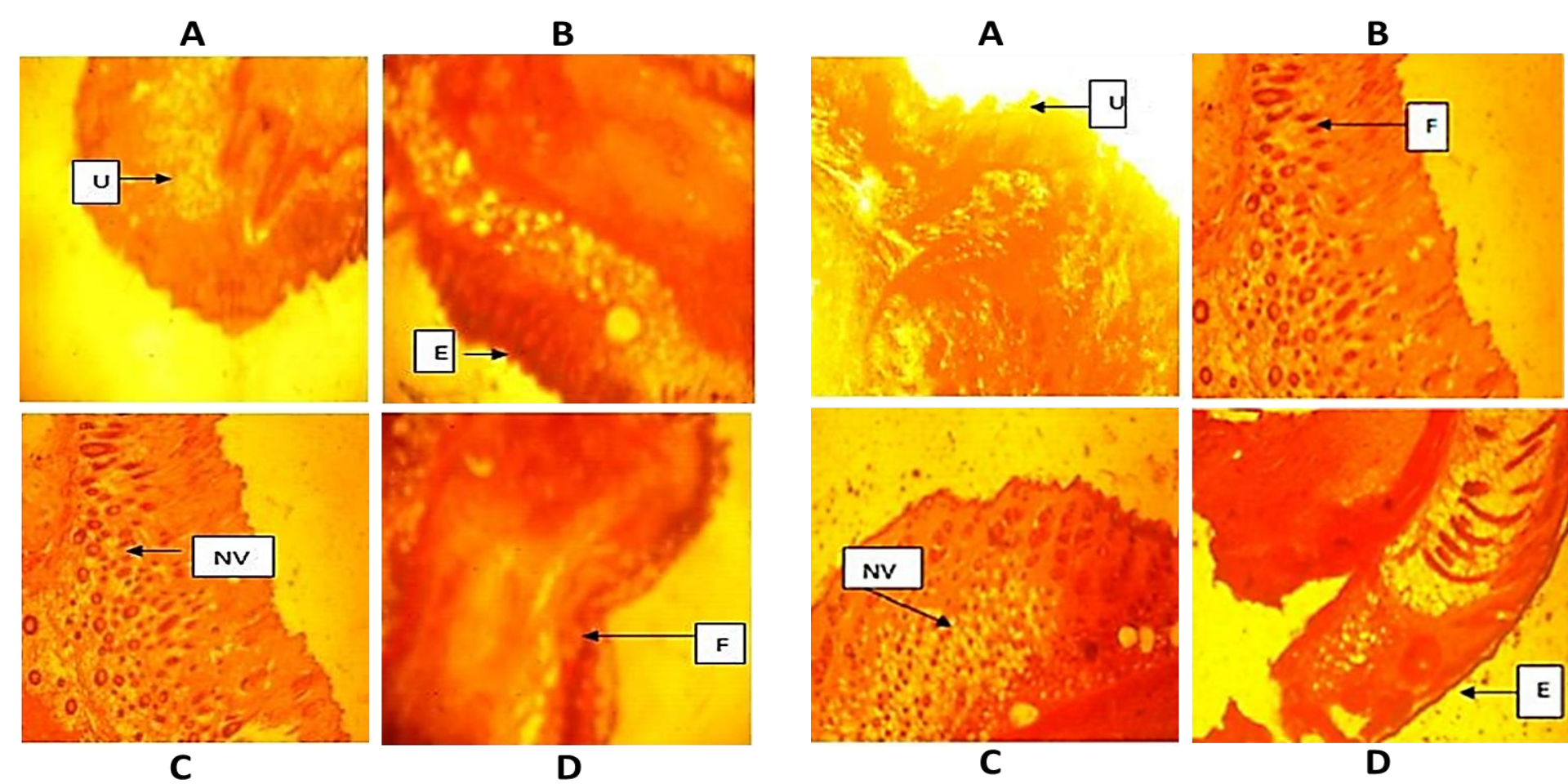

\section{Day 6}

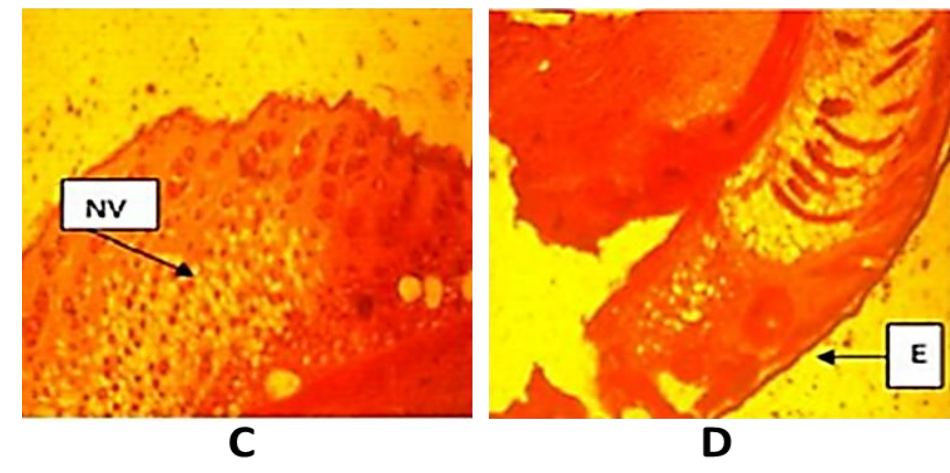

Figure 3: Histological sections of skin wounds on day 6 (left) and day 12 (right) Light microscope structure of the burn wounds. H and $\mathrm{E}$ staining, magnification $\times 200$. Abbreviations: $\mathrm{A}=\mathrm{Gel}$ control; $\mathrm{B}=\mathrm{Gel}+$ C. planchonii $2.5 \% ; \mathrm{C}=\mathrm{Gel}+$ C. planchonii $5 \% ; \mathrm{D}=\mathrm{Brulex} \circledast \mathrm{B} . \mathrm{F}=($ Fibroblasts $), \mathrm{NV}=(\mathrm{Neovessels}), \mathrm{E}=($ Epithelialization $)$ and $\mathrm{U}=(\mathrm{Ulceration})$ 
Table 1: Summary of histological observations at the sixth treatment session.

\begin{tabular}{lcccccccc}
\hline Treatments & $\mathbf{C}$ & Ed & IC & N & F & NV & E & U \\
\hline Control & $* * *$ & $* * *$ & $* * *$ & $* *$ & $*$ & $*$ & - & $* * *$ \\
Gel + C. planchonii 2.5\% & $*$ & $*$ & $*$ & $*$ & $* *$ & $* *$ & $* *$ & $*$ \\
Gel + C. planchonii 5\% & $*$ & $*$ & $*$ & $*$ & $* *$ & $* *$ & $* * *$ & $*$ \\
Brulex ${ }^{\circledR}$ & $*$ & $*$ & $*$ & $*$ & $* *$ & $* *$ & $* * *$ & $*$
\end{tabular}

Abbreviations: $(-)=$ Absent,$(*)=$ Minimal presence, $(* *)=$ Moderate presence, $(* * *)=$ Marked presence. $\mathrm{C}=($ congestion $)$, $\mathrm{Ed}=($ Oedema $), \mathrm{IC}=($ Inflammatory cells $), \mathrm{N}=($ Necrosis $), \mathrm{F}=($ Fibroblasts $), \mathrm{NV}=($ Neovessels $), \mathrm{E}=($ Epithelialization $)$ and $\mathrm{U}=($ Ulceration$)$.

Table 2: Summary of histological observations on the twelfth day of treatment.

\begin{tabular}{lcccccccc}
\hline Treatments & $\mathrm{C}$ & $\mathrm{Ed}$ & $\mathrm{IC}$ & $\mathrm{N}$ & $\mathrm{F}$ & $\mathrm{NV}$ & $\mathrm{E}$ & $\mathrm{U}$ \\
\hline Gel control & - & - & - & - & $*$ & $*$ & $*$ & - \\
Gel + C. planchonii $2.5 \%$ & - & - & - & - & $* *$ & $* *$ & $* * *$ & - \\
Gel + C. planchonii $5 \%$ & - & - & - & - & $* *$ & $* *$ & $* * *$ & - \\
Brulex® & - & - & - & - & $* *$ & $* *$ & $* * *$ & - \\
\hline
\end{tabular}

Abbreviations: $(-)=$ Absent,$(*)=$ Minimal presence, $(* *)=$ Moderate presence, $(* * *)=$ Marked presence. $\overline{\mathrm{C}}=($ congestion$)$, $\mathrm{Ed}=($ Oedema $), \mathrm{IC}=($ Inflammatory cells $), \mathrm{N}=($ Necrosis $), \mathrm{F}=($ Fibroblasts $), \mathrm{NV}=($ Neovessels $), \mathrm{E}=($ Epithelialization $)$ and $\mathrm{U}=$ (Ulceration).

\section{DISCUSSION}

Wounds can be defined as injuries occurring in living tissues that are usually caused by a cut, blow, burn or other impact, typically one in which the skin is cut or broken. Preheated materials applied directly on the skin are usually used to induce this type of wound (Cai et al., 2014; Said et al., 2019; Seyhan, 2020). The restoration of the disturbed functional status of the skin and disrupted anatomical continuity requires proper wound healing. In this study, we used two Carbopol gels containing respectively $2.5 \%$ and $5 \%$ of Cochlospermum planchonii hydroethanolic extract. The rising of wounds contractions rate's found after twelve days of treatment, $+53.71 \%,+51.13 \%,+57.11 \%$ respectively for $2.5 \%, 5 \%$ and Brulex ${ }^{\circledR}(\mathrm{P}<0.01$ compared to control mice), indicates clearly that this plant extract accelerates the restoration of the skin. Elsewhere, studies carried out using various plant extracts in gels, ointment or creams gave similar results. Celosia argentea extract ointment $(10 \%)$ for example, induced early wound closure in the rats when compared with control group after 21 days $(\mathrm{P}<0.001)$ (Guo et al., 2016). Sauromatum guttatum extract ( $2 \%$ w/w), in another study, decreased by $72 \%$ the rate of wound area with topical ointment prepared in petroleum jelly (Said et al., 2019).

Regarding mechanisms, our previous data (Fankibe et al., 2020) have reported the presence of metabolites (flavonoids, tannins, carbohydrates, sterols, triterpenes, and saponosides) in the leaves and root hydroethanolic extracts of this plant, as also reported elsewhere (Da et al., 2015; Kallo et al., 2018). In fact, many studies that have highlighted the variations in concentration of secondary metabolites from plant to plant species as well as in the different parts of a plant, leaves and roots being the preferential sites of accumulation of these compounds (Kantati et al., 2016). Polyphenolic compounds, in particular have well known antioxidant activities (Pandey and Rizvi, 2009; Cory et al., 2018; Taillé et al., 2020). The accelerated wound healing observed in this study would then be linked to the phytochemical composition of the plant. In addition, Fankibe et al. (2020) have reported antimicrobial activities of leaves and roots of $\mathrm{C}$. planchonii hydroethanolic extracts against four common pathogenic bacteria isolated from 
wounds (Staphylococcus aureus, Escherichia coli, Pseudomonas aeruginosa, and Klebsiella pneumonia). Since infection installation is the most common and inevitable impediment to wound healing (Church et al., 2006; Negut et al., 2018), wound dressings loaded with antimicrobial agents have emerged as viable options to reduce wound bacterial colonization and infection, in order to improve the healing process. Tannins in particular, found in $C$. planchonii, exhibits antiseptic, anti- microbial and anti- fungal activities (Aron and Kennedy, 2008). They have the ability to trap free radicals and inhibit the formation of the superoxide radicals. Tannins are also generally endowed with an astringent power that gives them vasculoprotective and healing properties (Hennebelle et al., 2004), in addition to their anti-oxidant and anti-inflammatory activities (Wang et al., 2002). Antibacterial activity and antioxidant compounds found in this plant should explain the ability of Cochlospermum planchonii to cleanse the wound and allow the healing process to take place normally.

\section{Conclusion}

Our study focused on the efficacy of the hydroethanolic roots extract of Cochlospermum planchonii on the healing of burn wounds in mice. The contraction rate, hydroxyproline levels and the nature of the histological tissue obtained after twelve days of application of the hydroethanolic extracts of Cochlospermum planchonii, allow us to conclude that the hydro-alcoholic extract of Cochlospermum planchonii could be a potential natural remedy for burn wounds.

\section{COMPETING INTERESTS}

The authors declare that there are no competing interest regarding the publication of this paper.

\section{AUTHORS' CONTRIBUTIONS}

$\mathrm{NF}$ was the principal investigator in the work presented here. KM designed the study and directed data acquisition. Data analyses and the manuscript elaboration were realised by YTK. AK helped in data acquisition. DT directed histological studies. KE-G is assistant to the director of the laboratory and KAA is the director of the laboratory of Physiology/Pharmacology, University of Lomé, Togo.

\section{ACKNOWLEDGMENTS}

We are grateful to the members of the Department of Anatomy and Cytopathology, Sylvanus Olympio University Hospital Center, Lomé-Togo, who participated in this study. We are also grateful to the staff members of the Laboratory of Physiology/Pharmacology of University of Lome-Togo.

\section{REFERENCES}

Adjakpa JB, Ahoton LE, Obossou FK, Ogougbé C. 2016. Ethnobotanical study of Senegal custard apple (Annona senegalensis Pers.) in DassaZoumétownship, Republic of Benin. Int. J. Biol. Chem. Sci., 10(5): 2123-2137. DOI:

https://doi.org/10.4314/ijbcs.v10i5.15

Agra IK, Pires LL, Carvalho PS, Silva-Filho EA, Smaniotto S, Barreto E. 2013. Evaluation of wound healing and antimicrobial properties of aqueous extract from Bowdichia virgilioides stem barks in mice. An. Acad. Bras. Ciênc., 85(3): $945-954 . \quad$ DOI: http://dx.doi.org/10.1590/S000137652013005000049

Anaga AO, Oparah N. 2009. Investigation of the methanol root extract of Cochlospermum planchonii for pharmacological activities in vitro and in vivo. Pharm. Biol., 47(11): 1027-1034. DOI:

https://doi.org/10.3109/13880200902973 795

Aron PM, Kennedy JA. 2008. Flavan-3-ols: Nature, occurrence and biological activity. Mol. Nutr. Food Res., 52(1): 79104.

DOI: https://doi.org/10.1002/mnfr.200700137

Barros AS, Carvalho HO, dos Santos IVF, Taglialegna T, dos Santos Sampaio TI, Duarte JL. 2017. Study of the non-clinical healing activities of the extract and gel of Portulaca pilosa L. in skin wounds in wistar rats: A preliminary study. Biomed. Pharmacother., 96: 182-190. DOI: 
https://doi.org/10.1016/j.biopha.2017.09. 142

Benoit-Vical F, Santillana-Hayat M, KoneBamba D, Mallie M, Derouin FJP. 2000. Anti-Toxoplasma activity of vegetal extracts used in West African traditional medicine. Parasite, 7(1): 3-7. DOI : https://doi.org/10.1051/parasite/2000071 003

Benoit-Vical F, Valentin A, Mallié M, Bessière JM. 2001. Antiplasmodial Activity of Cochlospermum planchonii and $C$. tinctorium Tubercle Essential Oils. $J$. Essent. Oil Res., 13(1): 65-67. DOI : https://doi.org/10.1080/10412905.2001.9 699609

Cai EZ, Ang CH, Raju A, Tan KB, Hing EC, Loo Y, Lim TC. 2014. Creation of consistent burn wounds: a rat model. Arch. Plast. Surg., 41(4): 317-324. DOI : https://doi.org/10.5999/aps.2014.41.4.31 7

Church D, Elsayed S, Reid O, Winston B, Lindsay R. 2006. Burn wound infections. Clin. Microbiol. Rev., 19(2): 403-434. DOI: https://doi.org/10.1128/CMR.19.2.403434.2006

Cory H, Passarelli S, Szeto J, Tamez M, Mattei J. 2018. The role of polyphenols in human health and food systems: a mini-review. Front. Nutr., 5: $87 . \quad$ DOI: https://doi.org/10.3389/fnut.2018.00087

Da O, Coulibaly MT, Ouédraogo JCW, Yaro B, Yerbanga RS, Kini F, Matsabisa MG. 2015. Phytochemical screening of Saye, a traditional herbal remedy for malaria. Int. J. Biol. Chem. Sci., 9(6): 2940-2946. DOI : http://dx.doi.org/10.4314/ijbcs.v9i6.33

Darré T, Metowogo K, Lawson-Evi P, EkluGadegbeku K, Aklikokou KA, NapoKoura G, Gbeassor M. 2014. Effet topique de l'extrait hydroethanolique de l'acacia nilotique sur la cicatrisation cutanée des brulures de second degré. Eur. Sci. J., 10(30): 212-221. DOI: https://doi.org/10.19044/esj.2014.v10n30 $\mathrm{p} \% 25 \mathrm{p}$

Fankibe N, Metowogo K, Kantati YT, Afanyibo Y-G, Lawson-Evi P, Mouzou A, Eklu-Gadegbeku K, Aklikokou AK. 2020. Phytochemical screening and antimicrobial activities of leaves and roots extract of Cochlospermum planchonii (Bixaceae). J. Pharmacognosy Phytother., 12(4): 94-101. DOI: https://doi.org/10.5897/JPP2020.0591 .

Guo WZ, Di H, Bao R, Chu GH, Tang XH, Feng M, Lu LJM. 2016. The healing effect of Celosia argentea leaf extract on burn wounds: An in vivo and in vitro evaluation. Int. J. Clin. Exp. Med., 9: 21018-21027.

Haghdoost F, Baradaran Mahdavi MM, Zolfaghari B, Sanei MH, Najafi S, Zandifar A, Manouchehri N, Javanmard SH. 2016. The effect of Quercus brantii gall extract on burn wound healing in rat. Iran. J. Basic Med. Sci., 19(10): 11441150.

Hennebelle T, Sahpaz S, Bailleul F. 2004. Polyphénols végétaux, sources, utilisations et potentiel dans la lutte contre le stress oxydatif. Phytothérapie, 2(1): 36. DOI : https://doi.org/10.1007/s10298004-0003-8

Isah Y, Ndukwe I, Ayo RJM, Res HT. 2013. Phytochemical and antimicrobial analyses of stem-leaf of Cochlospermum planchonii. J. Med. Plant Herbal Ther. Res., 1: 13-17. DOI: https://doi.org/10.33500/jmphtr.2013.1.0 03

Izah SC, Uhunmwangho E, Eledo BPR. 2018. Medicinal potentials of Buchholzia coriacea (wonderful kola). Med. Plant Res., 8(5): 27- 42. DOI: https://doi.org/10.5376/mpr.2018.08.000 5

Kallo MS, Adamou R, Sawadogo J, Mahamane AA, Maarouhi IM, Ikhiri K. 2018. Enquête ethnobotanique et criblage phytochimique de quelques plantes tinctoriales du Niger en vue d'une valorisation en énergie solaire. Int. J. Biol. Chem. Sci., 12(2): 867-883. DOI : https://dx.doi.org/10.4314/ijbcs.v12i2.20

Kantati YT, Kodjo KM, Dogbeavou KS, Vaudry D, Leprince J, Gbeassor M. 2016. Ethnopharmacological survey of plant species used in folk medicine against central nervous system disorders in Togo. J. Ethnopharmacol., 181: 214-220. DOI : 
http://dx.doi.org/10.1016/j.jep.2016.02.0 06

Koizumi T, Goto H, Tanaka H, Yamaguchi Y, Shimazaki S. 2009. Lecithinized superoxide dismutase suppresses free radical substrates during the early phase of burn care in rats. J. Burn Care Res., 30(2): 321-328. DOI: https://doi.org/10.1097/BCR.0b013e318 $198 \mathrm{e} 764$

Natas S`K, Mira C, Ivan J. 2008. Liposomes with metronidazole for topical use: the choice of preparation method and vehicle. J. Liposome Res., 8(2): 283-293. DOI : https://doi.org/10.3109/08982109809035 532

Negut I, Grumezescu V, Grumezescu AM. 2018. Treatment strategies for infected wounds.

Molecules, 23(9): 2392. DOI: https://doi.org/10.3390/molecules230923 92

Nicoli S, Padula C, Aversa V, Vietti B, Wertz PW, Millet A, Falson F, Govoni P, Santi P. 2008. Characterization of rabbit ear skin as a skin model for in vitro transdermal permeation experiments: histology, lipid composition and permeability. Skin Pharmacol. Physiol., 21(4): 218-226. DOI: https://doi.org/10.1159/000135638

Pandey KB, Rizvi SI. 2009. Plant polyphenols as dietary antioxidants in human health and disease. Oxid. Med. Cell Longev., 2(5): 270-278. DOI: https://doi.org/10.4161/oxim.2.5.9498

Peden M, Oyegbite K, Ozanne-Smith J, Hyder AA, Branche C, Rahman AKMF, Rivara F, Bartolomeos K. 2008. World Report on Child Injury Prevention. World Health Organization, Geneva.

Said A, Wahid F, Bashir K, Rasheed HM, Khan T, Hussain Z, Siraj S. 2019. Sauromatum guttatum extract promotes wound healing and tissue regeneration in a burn mouse model via up-regulation of growth factors. Pharm. Biol., 57(1): 736-
743.

DOI:

https://doi.org/10.1080/13880209.2019.1 676266

Sene M, Barboza FS, Top B, Ndiaye M, Sarr A, Fall AD, Sy GY. 2020. Wound healing activity of the aqueous leaf extract of Elaeis guineensis Jacq. (Arecaceae). Int. J. Biol.Chem. Sci., 14(3): 674-684. DOI : https://doi.org/10.4314/ijbcs.v14i3.3

Seyhan N. 2020. Evaluation of the Healing Effects of Hypericum perforatum and Curcumin on Burn Wounds in Rats. Evid. Based Complement. Alternat. Med., 2020: 6462956.

DOI: https://doi.org/10.1155/2020/6462956

Taïlé J, Arcambal A, Clerc P, Gauvin-Bialecki A, Gonthier MP. 2020. Medicinal Plant Polyphenols Attenuate Oxidative Stress and Improve Inflammatory and Vasoactive Markers in Cerebral Endothelial Cells during Hyperglycemic Condition. Antioxidants, 9(7): 573. DOI : https://doi.org/10.3390/antiox9070573

Wang J, Mazza, GJ, Chemistry F. 2002. Effects of anthocyanins and other phenolic compounds on the production of tumor necrosis factor $\alpha$ in LPS/IFN- $\gamma$-activated RAW 264.7 macrophages. J. Agr. Food Chem., 50(15): 4183-4189. DOI : https://doi.org/10.1021/jf011613d

Yakubu MT, Akanji MA, Nafiu MO. 2010. Anti-diabetic activity of aqueous extract of Cochlospermum planchonii root in alloxan-induced diabetic rats. Cameroon J. Exp. Biol., 6(2): 91-100. DOI : https://doi.org/10.4314/cajeb.v6i2.68526

Yoda J, Ouedraogo JC, Ouedraogo S, TraoreCoulibaly M, Kini F, Lompo M, Ouedraogo SJC. 2020. Standardisation Process of Saye, a Traditional Polyherbal Formulation Remedy for Malaria: Physico-chemical Analysis and Phytochemical Investigation. Sci. J. Anal. Chem., 8(1): 33-40. DOI: https://doi.org/10.11648/j.sjac.20200801. 16. 